\title{
THE ROLE OF UPWARD INFLUENCE TACTICS IN HUMAN RESOURCE DECISIONS
}

\author{
SANDY J. WAYNE, ROBERT C. LIDEN, ISABEL K. GRAF \\ University of Illinois at Chicago \\ GERALD R. FERRIS \\ University of Illinois at Urbana-Champaign
}

\begin{abstract}
A model was examined which proposes that employee influence tactics impact human resource decisions by affecting managers' perceptions of the subordinate's interpersonal skills, manager liking of subordinates, and managers' perceptions of similarity to subordinates. The human resource decisions investigated were performance ratings, promotability assessments, and salary. Data were collected from 247 subordinates and their managers and from company records. Structural equation modeling results indicated that influence tactics were related to managers' perceptions of subordinates' interpersonal skills, liking, and perceptions of similarity to subordinates. Specifically, subordinates' use of reasoning, assertiveness, and favor rendering were positively related to managers' perceptions whereas bargaining and self-promotion were negatively related to these perceptions. Finally, there was no support for direct relationships between influence tactics and HR decisions.
\end{abstract}

Human resource decisions are embedded in a complex and dynamic social context. Indeed, to develop an informed understanding of decisions such as performance evaluation, promotions, and salary increases, we must embrace the dynamic aspects of the context, and realize that participants are active players in shaping reality and influencing decisions (Ferris \& Judge, 1991). Over 30 years ago, researchers began to identify employees as not simply passive, but rather as proactive participants engaged in active efforts to alter their work environments (Lowin \& Craig, 1968). Subsequent research has focused on identifying behaviors used by employees in affecting their environments and target individuals within those contexts (e.g., Hollander \& Offermann, 1990; Wortman \& Linsenmeier, 1977).

A particular set of behaviors that employees use to impact their work environments is upward influence, which refers to an agent's behaviors that are directed toward individuals at higher levels in the organizational

This research was supported by a grant from the Center for Human Resource Management at the University of Illinois.

Correspondence and requests for reprints should be addressed to Sandy J. Wayne, Department of Managerial Studies (M/C 243), College of Business Administration, 601 South Morgan Street, Chicago, IL 60607-7123, e-mail: SJWAYNE@UIC.EDU 
hierarchy. The literature on upward influence has focused on developing taxonomies and measures of influence tactics (Kipnis, Schmidt, \& Wilkinson, 1980; Schriesheim \& Hinkin, 1990), identifying when agents make upward influence attempts (Gardner \& Martinko, 1988), determining agent choice of influence strategies (Liden \& Mitchell, 1988), and assessing the effect of upward influence behaviors on target reactions (Schilit \& Locke, 1982; Yukl \& Tracey, 1992). Especially rare in the literature have been investigations examining the effects of influence tactics on individual outcomes such as performance ratings, promotability, and salary (Ferris \& Judge, 1991; Kipnis \& Schmidt, 1988). Of these studies, most have examined direct associations between influence tactics and outcomes (Dreher, Dougherty, \& Whitely, 1989; Judge \& Bretz, 1994; Kipnis \& Schmidt, 1988; Thacker \& Wayne, 1995). Essentially ignored in empirical research has been the way in which influence tactics may affect decision-maker perceptions, which in turn lead to outcomes that reflect career success (Feldman \& Klich, 1991). In addition, most of the studies have focused on a single human resources decision, with particular attention devoted to performance evaluation (Ferris, Judge, Rowland, \& Fitzgibbons, 1994; Kipnis \& Schmidt, 1988; Wayne \& Ferris, 1990; Wayne \& Kacmar, 1991; Wayne \& Liden, 1995).

The purpose of this study was to test a model of the mediating processes which explains the linkages between influence tactics and several human resource decisions. The proposed model expands on theory development by Ferris and Judge (1991) by articulating the process by which employee influence tactics affect the human resource decisions of performance ratings, promotability assessments, and salary progression.

\section{Model Development and Hypotheses}

Ferris and Judge (1991) presented a political influence perspective on human resource management, and a general framework which suggested that supervisor liking, perceptions of competence, and perceptions of similarity serve as mediators between influence tactics and human resource decisions. Although the Ferris and Judge framework was intended to stimulate research interest on influence tactics and human resource decisions, their conceptualization lacked the precision of proposing how each influence tactic might be related to the three intermediate linkages. Therefore, additional theoretical depth needs to be provided to permit empirical testing of a model of the intervening processes between influence tactics and human resource decisions.

The model, presented in Figure 1, proposes specific linkages between six upward influence tactics and three key target reactions, and linkages between target reactions and human resource decisions including per- 

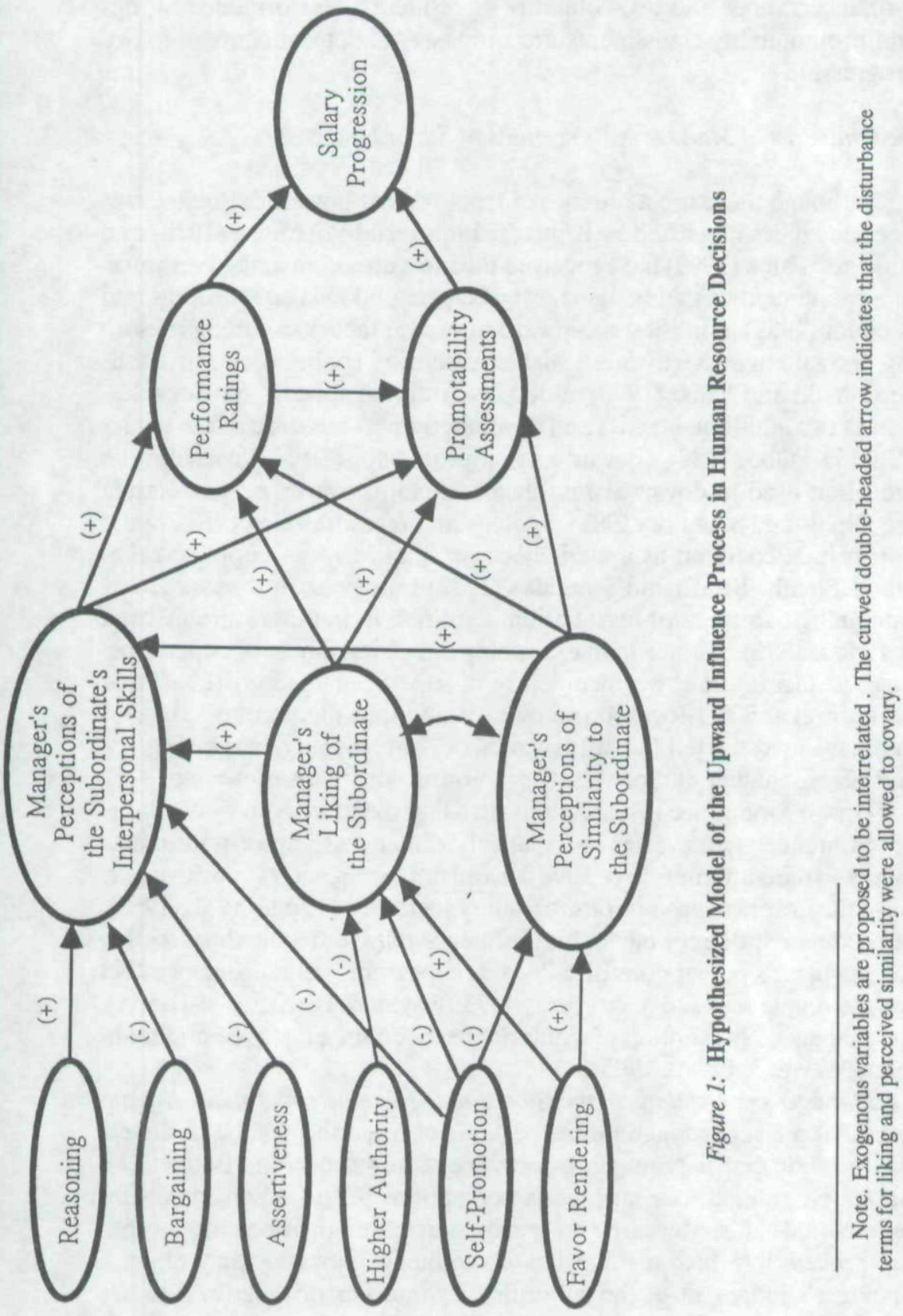
formance ratings and promotability assessments. Performance ratings and promotability assessments are proposed as determinants of salary progression.

\section{Determinants of Manager's Perceptions of Subordinates}

Although there are a number of typologies of upward influence tactics, the tactics identified by Kipnis, Schmidt, and Wilkinson (1980) and Yukl and Falbe (1990) have received the most attention in the literature. In a refinement of their original set of tactics and measures, Kipnis and Schmidt (1982) identified six upward influence tactics including reasoning, bargaining, assertiveness, higher authority, coalition, and friendliness. Yukl and Falbe (1990) added inspirational appeals and consultation as two additional tactics and developed a new measure of the tactics (Yukl \& Falbe, 1980). Because inspirational appeals and consultation are often used in downward influence attempts, we chose to examine the Kipnis and Schmidt (1982) typology and measure. However, we did not include coalition as a tactic because it had an unacceptable reliability. Finally, Kipnis and Schmidt's (1982) framework was extended by examining two types of ingratiation identified in the literature (Wayne \& Liden, 1995). Rather than examining only friendliness or supervisorfocused ingratiation, we included both supervisor-focused (i.e., favor rendering) and self-focused (i.e., self-promotion) ingratiation. In summary, we investigated the influence tactics of reasoning, bargaining, assertiveness, higher authority, self-promotion, and favor rendering.

Upward influence research indicates that the effectiveness of different influence tactics varies and that subordinates use upward influence tactics in their attempts to receive desired outcomes, such as positive performance ratings, promotions, or salary increases (Kipnis et al., 1980). Subordinate influence tactics may influence these outcomes by affecting the manager's perceptions of skills or competence, the manager's affect for the employee (Judge \& Ferris, 1993; Wayne \& Ferris, 1990), and/or the manager's perception of similarity between the employee and manager (Wayne \& Liden, 1995).

Manager's perceptions of the subordinate's interpersonal skills. We expect that the subordinate influence tactic of reasoning will be positively related, but that bargaining, assertiveness, and self-promotion will be negatively related to a manager's perceptions of the subordinate's interpersonal skills. Research on person perception provides insight into the process by which a subordinate's influence behavior may affect a manager's judgment of the subordinate's interpersonal skills. Studies on person perception indicate that individuals tend to generalize their judgments of another person (Ross, Greene, \& House, 1977) and infer a 
more general trait from another person's behavior (Srull \& Wyer, 1989). Extending these findings to upward influence suggests that a manager may assume that a subordinate's influence behavior targeted at them is representative of the way the subordinate interacts with others in the organization and thus, reflects a skill. In addition, the manager may infer that the subordinate possesses certain traits or skills based on the type of tactic used. Both of these processes suggest that subordinate's influence behavior will affect managers' judgments concerning the subordinate's interpersonal skills. Further, these judgments will be either positive or negative, depending on the type of influence tactic.

Research has shown that there is a positive relationship between employee use of reasoning and evaluations made by the manager (Kipnis \& Schmidt, 1988; Yukl \& Tracey, 1992). Thus, a subordinate who uses reasoning in interactions with the manager may lead the manager to assume that the subordinate will use reasoning in other situations as well and infer that the use of reasoning is associated with effective interpersonal skills. For example, a manager may consider an employee who provides logical arguments, presents factual evidence, and offers clear explanations to support his or her viewpoint as possessing effective interpersonal skills.

Hypothesis 1a: A subordinate's use of reasoning will be positively related to the manager's perceptions of the subordinate's interpersonal skills.

Although some upward influence tactics have a positive effect on manager perceptions of subordinate interpersonal skills, others, such as bargaining, assertiveness, and self-promotion, may produce a negative manager impression. Bargaining tactics involve a subordinate's attempt to influence the manager by complying with the manager only if the manager provides something of value in return. Managers often expect subordinates to carry out their requests without needing to promise that something will be provided in return. Thus, managers may respond negatively to a subordinate's use of bargaining. Supporting this view, anthropological research on social exchange has demonstrated that people value generalized reciprocation, which involves exchanges that are not predicated on immediate and equal returns. In fact, generalized reciprocity is favored over balanced reciprocity, which is comprised of negotiated exchanges involving a quid pro quo. Furthermore, individuals tend to resent negotiated exchanges when a generalized form of reciprocation is anticipated (Gouldner, 1960; Sahlins, 1972). When subordinates engage in bargaining with the manager, the manager may view this as inappropriate behavior and assume that this is characteristic of the subordinate's behavior with others in the organization. This, in turn, 
may cause the manager to perceive the subordinate to have poor interpersonal skills.

Managers may also respond negatively to assertiveness tactics. Assertiveness includes behaviors such as confronting the manager, becoming a nuisance, repeatedly reminding the manager, and verbally expressing anger. This tactic tends to be used more frequently in downward influence attempts (by a supervisor attempting to influence a subordinate) in comparison to upward influence attempts (Kipnis et al., 1980; Yukl \& Falbe, 1990). As a result, managers may view this tactic as inappropriate in upward influence attempts. Empirical studies support this contention. In a study by Kipnis and Schmidt (1988), the influence style which emphasized assertiveness was associated with lower performance ratings. Similarly, Schilit and Locke (1982) found that tactics viewed by superiors as challenging their power tended to be unsuccessful, and Falbe and Yukl (1992) found assertive behaviors as one of the least effective influence tactics. However, Yukl and Tracey (1992) found a nonsignificant relationship between subordinate assertive behaviors and the manager's rating of the subordinate's effectiveness. Finally, in a recent study by Thacker and Wayne (1995) subordinate use of assertiveness, as reported by the supervisor, was negatively related to supervisor assessments of the subordinate's promotability. Based on these studies, we expected assertiveness to be negatively related to manager's perceptions of the subordinate's interpersonal skills.

A third influence tactic that managers may respond negatively to is self-promotion. Successful use of self-promotion tactics is extremely difficult because when only slightly overdone, it is interpreted as bragging or conceit (Cialdini \& DeNicholas, 1989; Wortman \& Linsenmeier, 1977). Also, self-promotion has been shown to generate negative target ratings of the agent's sociability (Gurevitch, 1984) and job-related interpersonal skills (Baron, 1986).

Hypothesis 1b: A subordinate's use of bargaining, assertiveness, and selfpromotion will be negatively related to the manager's perceptions of the subordinate's interpersonal skills.

Manager's liking of the subordinate. The influence tactic of favor rendering, often labeled as a form of ingratiation (Kipnis \& Schmidt, 1988; Kumar \& Beyerlein, 1991), should be positively related to managers' liking of subordinates. Individuals may render favors for the purpose of ingratiating themselves with targets (Kipnis \& Schmidt, 1988; Liden \& Mitchell, 1988; Wortman \& Linsenmeier, 1977). Based on Heider's (1958) balance theory, if a subordinate does a favor that the manager appreciates, the manager may be induced to like the subordinate in order to maintain balance in the relationship. Research in organizational 
settings has shown that subordinate favor doing positively relates to manager's reports of liking toward the subordinate (Ferris et al., 1994; Wayne \& Ferris, 1990; Wayne \& Liden, 1995).

Hypothesis 2a: A subordinate's use of favor rendering will be positively related to manager's liking of the subordinate.

Self-promotion is perhaps the most transparent influence strategy, making it very difficult to use without revealing an ulterior motive (Cialdini \& DeNicholas, 1989; Wortman \& Linsenmeier, 1977). When the target of a self-promotion tactic perceives the behavior as reflecting an ulterior motive, it induces dislike of the agent. Studies indicate that agents typically do not succeed in using self-promotion tactics. For example, self-promotion has been found to be unrelated (Wayne \& Ferris, 1990; Wayne \& Liden, 1995) or negatively related (Baron, 1986; Judge \& Bretz, 1994) to target liking and outcomes such as career success.

Hypothesis 2b: A subordinate's use of self-promotion will be negatively related to the manager's liking of the subordinate.

The tactic of upward appeals is where subordinates obtain the support of higher-level managers in order to influence their managers (Kipnis et al., 1980). Subordinates who bypass their managers in attempts to gain influence will be viewed as threatening and will not be liked by managers. This is not to suggest that all subordinate interaction with higher-level individuals will result in negative reactions by the manager. Establishing network ties with higher level individuals may be indicative of power possession (Brass \& Burkhardt, 1993). When such power is exercised on behalf of the work unit, it will be viewed positively by the manager, but when it is used to circumvent the manager, it will be viewed with disdain. Consistent with this view, research has suggested that use of harsh influence tactics, such as upward appeals, are negatively related to liking (Michener \& Schwertfeger, 1972).

Hypothesis 2c: A subordinate's use of higher authority will be negatively related to the manager's liking of the subordinate.

Manager's perceptions of similarity to the subordinate. Because of the significant correlation between liking and perceived similarity (Byrne, 1971; Liden, Wayne, \& Stilwell, 1993), it follows that liking and perceived similarity share some of the same antecedents. One of these shared correlates is favor rendering, which has been shown to be related both to liking and perceived similarity. In fact, a pervasive effect in social psychology is that people tend to perceive themselves as similar to individu- 
als who exhibit positive behaviors such as rendering favors (Byrne, 1971; Johnson, 1989; Newcomb, 1961). Perceiving oneself as similar to a person who engages in desirable behaviors represents one way of affirming one's self-image (Swann, Stein-Seroussi, \& Giesler, 1992).

Hypothesis 3a: A subordinate's use of favor rendering will be positively related to the manager's perceptions of similarity to the subordinate.

Contrary to favor-rendering, subordinate self-promotion behaviors are expected to result in manager perceptions of dissimilarity with the subordinate. Individuals who engage in self-promotion behaviors tend to be perceived by targets as being egotistical or conceited (Cialdini \& DeNicholas, 1989; Holtgraves \& Srull, 1989). Research has demonstrated that most individuals, especially those who view themselves positively, do not perceive that they are similar to undesirable people (Byrne, 1971; Swann et al., 1992; Wayne \& Liden, 1995).

Hypothesis $3 b$ : A subordinate's use of self-promotion will be negatively related to the manager's perceptions of similarity to the subordinate.

\section{Linkages Among Intervening Variables}

Based on a cognitive information processing model (Feldman, 1986), we expect that manager's liking of the subordinate and perceptions of similarity to the subordinate will be positively associated with the manager's perceptions of the subordinate's interpersonal skills. Specifically, an individual will tend to categorize another person on the basis of a few interactions and then later recall information and evaluate the other person based on that categorization. Thus, if a manager likes an employee or perceives the employee to be similar to him or herself, then the manager is likely to categorize information about that employee in a favorable manner and subsequently evaluate the employee's interpersonal skills favorably. Longitudinal research has not provided evidence for paths from interpersonal skills to liking or to perceived similarity, as results indicate that liking and perceived similarity develop prior to judgments about performance or skills (Liden et al., 1993). However, theory and previous research suggest that liking and perceived similarity are correlated (Byrne, 1971; Wayne \& Liden, 1995), which is represented by the double-headed curved arrow in Figure 1.

\section{Determinants of Managerial Ratings of Subordinate Performance}

Although validity problems and numerous biases have been uncovered in the performance evaluation literature (Bretz, Milkovich, \& Read, 
1992), research has shown that actual performance typically accounts for the majority of explained variance in performance ratings (Bigoness, 1976; Mitchell \& Liden, 1982). Research has demonstrated that jobrelated interpersonal skills are related both to ratings of job applicant hirability (Kinicki, Lockwood, Hom, \& Griffeth, 1990) as well as job performance (Bray \& Howard, 1980).

Manager liking of subordinates has been found to be related to managerial performance ratings in several studies (Cardy \& Dobbins, 1986; Ferris et al., 1994; Judge \& Ferris, 1993; Tsui \& Barry, 1986; Wayne \& Ferris, 1990; Wayne \& Liden, 1995). This effect may be due to rating bias occurring as the result of the influence that liking has on cognitive information processing (Robbins \& DeNisi, 1994). It is also possible that liking is associated with managers' provision of resources and support to subordinates that results in higher actual performance (Feldman, 1986).

Managers' perceptions of similarity to subordinates also tend to be related to performance ratings (Turban \& Jones, 1988; Wayne \& Liden, 1995). People appear to form perceptions of themselves and others by making comparisons to prototypes (London \& Smither, 1995). Due to self-serving attributional biases and tendencies to protect one's self-image, individuals generally perceive their self-schemas to parallel prototypes. Indeed, research shows that people tend to rate themselves positively (Atwater \& Yammarino, 1992). Likewise, the more similar to one's self that a comparison-other is perceived to be, the greater the overlap between the schema formed for that person and the prototype. It follows that similar others should be rated more positively than dissimilar others.

Hypothesis 4: A manager's perceptions of the subordinate's interpersonal skills, liking of the subordinate, and perceptions of similarity to the subordinate will be positively related to the manager's ratings of the subordinate's performance.

\section{Determinants of Subordinate Promotability Assessments}

Surprisingly few studies on the determinants of promotion decisions have been published since London and Stumpf (1983) noted that "despite the importance of promotions, we know little about how these decisions are made compared to other types of personnel decisions" (p. 242). These authors proceeded to show that promotion decisions are heavily influenced by potential or promotability. Promotability appears to be directly affected by individual characteristics such as education and skills (Markham, Harlan, \& Hackett, 1987) and by performance ratings (London \& Stumpf, 1983; Medoff \& Abraham, 1981). In addition to these "objective" variables that contribute to promotability, subjective 
information is also frequently used in determining who is viewed as promotable (Forbes, 1987).

Subjective information that is especially salient for career advancement is interpersonal skills (Bray \& Howard, 1980). Because a manager never has complete information on the skills and abilities of a subordinate, the manager relies on "signals" (Spence, 1973). Signals refer to information that is easily accessed or observed by the manager. Consistent with signaling theory, a manager may observe a subordinate's interactions and make assessments of his or her interpersonal skills based on these interactions. Because research has shown that managerial effectiveness is related to interpersonal skills (Pavett \& Lau, 1983), a manager's assessments of a subordinate's interpersonal skills will be positively related to the manager's perceptions of the subordinate's promotability.

Extrapolating from research on performance appraisal, it follows that a manager's liking of and perceived similarity to the subordinate should be related to the manager's perceptions of promotability. Specifically, the manager's liking of and perceived similarity to the subordinate are likely to bias the manager's recall of information when assessing the subordinate's performance and promotability (DeNisi \& Williams, 1988).

Hypothesis 5: A manager's perceptions of the subordinate's interpersonal skills, liking of the subordinate, perceptions of similarity to the subordinate, and performance ratings will be positively related to the manager's assessments of the subordinate's promotability.

\section{Determinants of Subordinate Salary Progression}

Studies employing a variety of designs have examined the relationship between performance ratings and salary increases. For example, field studies have found significant positive correlations between performance ratings and salary increases (e.g., Heneman, 1973; Medoff \& Abraham, 1981). Similarly, four experiments using college student subjects found that levels of manipulated job competence were positively related to reward allocations (Rusbult, Lowery, Hubbard, Maravankin, \& Neises, 1988). A policy-capturing study involving hospital managers found performance to be a significant variable in all participants' policies regarding salary raise decisions (Sherer, Schwab, \& Heneman, 1987). In another policy capturing study (Beatty, McCune, \& Beatty, 1988) performance was found to be the most important determinant of pay increases, relative to such variables as organizational commitment, need for achievement, education, and tenure. One limitation of these studies is that in all cases salary increases were measured at the same time 
as performance ratings (or competence manipulation in the experimental studies), and thus the causal order between these variables remains unknown.

In addition to ratings of current performance, perceptions of an individual's future success or promotability in the organization may serve as a predictor of salary progression. Medoff and Abraham (1981) argued that performance ratings and potential for advancement should be correlated but are not redundant. With a sample of 8,238 managers and professionals they found that potential for advancement significantly predicted number of promotions when performance ratings were controlled. Similarly, performance ratings predicted number of promotions when controlling for perceptions of potential for advancement. These results indicate the importance of performance ratings and perceptions of potential or promotability in predicting number of promotions. Given the parallel between number of promotions and salary progression, we expect that performance ratings and perceptions of promotability will be related to salary progression.

Studies have typically investigated either performance ratings or promotability, but have not assessed the relative importance of each in predicting salary increases. Whether one of the predictors is more important in explaining the variance in salary progression parallels the "performance-potential dilemma" that managers often face in making human resources decisions (Beer, Spector, Lawrence, Mills, \& Walton, 1984). Beer et al. (1984) argue that more subjective determinants of one's effectiveness and longer-range capacity to contribute drive decisions such as compensation in comparison to more immediate assessments of performance. Therefore, we expect that promotability assessments will be more strongly related to salary progression than performance ratings.

Hypothesis 6: A manager's performance ratings and perceptions of promotability will be positively related to the subordinate's salary progression.

\section{Method}

\section{Participants}

We conducted the study with several major business units of a large corporation which produces chemicals and machinery. A random sample of 1,413 exempt employees (referred to as subordinates throughout this paper) with at least 5 years of tenure with the organization were selected to participate in the study. The subordinate sample included 
managerial, professional, and technical employees in all functional areas of the organization (e.g., accounting, manufacturing, sales). A total of 570 subordinates completed the questionnaire ( $40 \%$ response rate). Subordinates included in the analyses had worked for their managers an average of 2 years and 10 months; $86 \%$ were males and $95 \%$ were Caucasian; $0.8 \%$ were in general management, $74.7 \%$ in line positions (e.g., marketing, sales, and manufacturing), and $24.5 \%$ in staff positions (e.g., finance, human resources, information systems). The subordinates held professional, technical, and managerial positions. The average age was 48 years old and average tenure with the organization was 16 years and 8 months. The average educational level was a bachelor's degree.

We also collected data from the subordinates' direct supervisors or managers. Because a few of the 570 participating subordinates reported to the same supervisor, 505 managers were sent surveys. Questionnaires were completed by 289 managers ( $57 \%$ response rate). Complete data were obtained for 247 dyads which was the sample size for all analyses. The manager sample was $95 \%$ male and $98 \%$ Caucasian. The average age for the manager sample was 45 years old and the average tenure with the organization was 15 years. The average educational level was a master's degree.

There were no significant differences between the subordinate respondents and nonrespondents in terms of organizational tenure, gender, and performance rating (from company records). Although those included in the sample had more education in comparison to those not included in the sample $(t=-3.16, p<.01)$, this effect explained less than one percent of the variance $\left(r_{p b}^{2}=.007\right)$. We were unable to compare respondents and nonrespondents on salary because these data were not available for nonrespondents.

\section{Procedures}

We mailed the subordinate and manager questionnaires directly to respondents' homes. A cover letter explained that the purpose of the study was to examine career-related issues, that participation in the study was voluntary, and that confidentiality of responses was guaranteed. All respondents were asked to return completed questionnaires to us. Approximately 5 weeks later, a follow-up mailing was conducted.

Both questionnaires had an identification number that allowed us to match subordinate and manager questionnaires, and to match the subordinates' responses with data from company records. The organization provided us with salary history, job history, and demographic information at the time of the initial data collection as well as salary history 18 months after the initial data collection. 
The data used in this study are from a larger organizational survey which has served as a basis for one other publication. One paper (Wayne, Shore, \& Liden, 1997) focused on examining perceived organizational support and leader-member exchange from a social exchange perspective. The current paper focuses on the role of upward influence tactics on human resource decisions and the intervening processes. Thus, the two papers are distinct and differ in terms of their purpose, theoretical foundation, and variables examined, with the exception of performance ratings which were included in both studies.

\section{Measures}

Influence tactics. Kipnis and Schmidt's (1982) Profile of Organizational Influence Strategies (POIS) was used to measure the influence tactics of reasoning, bargaining, assertiveness, and higher authority. The influence tactic of coalition was not included due to unacceptable reliability. Further, the Kipnis and Schmidt measure of friendliness was not used because it does not distinguish self-promotion from favor rendering. Thus, self-promotion and favor rendering were measured with six items from Kumar and Beyerlein's (1991) Measure of Ingratiating Behavior in Organizational Settings (MIBOS). We selected MIBOS items that had high loadings on appropriate factors in a factor analysis reported by Kumar and Beyerlein (1991). Prior evidence of the validity and reliability of the influence measures are provided in Kipnis, Schmidt, and Wilkinson (1980) and Kumar and Beyerlein (1991). For all of the influence tactics, subordinates indicated how frequently they used each of the tactics on a scale ranging from never (1) to always (7). Based on the results of a principal components analysis, the influence variables were created by summing the appropriate items. The reliabilities were .75 for reasoning, .76 for bargaining, .73 for assertiveness, .67 for higher authority, .75 for self-promotion, and .72 for favor rendering.

Interpersonal skills. Based on discussions with upper-level human resource executives and interviews with eight upper-level managers, we identified interpersonal skills such as communication and leadership skills that were appropriate for our sample. We then adapted eight items (with Permission from Personnel Decisions, Inc.) from skill definitions from the Management Skills Profile, The PROFILOR®, and The Executive Success Profile (copyrights 1982, 1991, and 1993, respectively). Interpersonal skills were assessed by managers and their responses, scaled poor (1) to outstanding (7), were summed (alpha $=.90$ ).

Liking. Liking was measured by three items from Wayne and Ferris (1990) such as "I think this employee would make a good friend." Man- 
agers responded on a 7-point scale ranging from strongly disagree (1) to strongly agree $(7)($ alpha $=.80)$.

Perceived similarity. Three items, such as "This employee and I are alike in a number of areas," were used to measure the manager's perceptions of the subordinate's similarity to the manager (Turban \& Jones, 1988). Managers' responses to the items were scaled strongly disagree (1) to strongly agree (7) (alpha $=.81)$.

Performance ratings. The manager rated the subordinate's performance on six items. Two of the performance rating items were from Tsui (1984): "Overall, to what extent has this employee been performing his/her job the way you would like it to be performed?" and "If you entirely had your way, to what extent would you change the manner in which this employee is performing his/her job" (reverse scored). Two items were adapted from Heilman, Block, and Lucas (1992): "All in all, this employee is very competent" and "In my estimation, this employee gets his or her work done very effectively." We developed two additional items: "Overall, to what extent has this employee been effectively fulfilling his/her roles and responsibilities?" and "Rate this employee's overall level of performance." All items were coded on a 5-point scale $($ alpha = $.90)$.

Promotability assessments. The manager assessed the promotability of the subordinate by responding to four items that we developed: "This employee will probably not be promoted to a higher level position at (organization name)" (reverse scored), "It would be best for (organization name) if this employee was not promoted from his/her current level during the next 5 years" (reverse scored), "I believe that this employee has what it takes to be promoted to a higher-level position," and "If I had to select a successor for my position, it would be this employee." Managers responded on scales ranging from strongly disagree (1) to strongly agree (7) $($ alpha $=.87)$.

Salary progression. Salary progression was defined as the percentage increase in salary from the time the survey data were collected to 18 months later. These data were obtained from company salary records.

\section{Results}

\section{Development and Validation of Measures}

Before testing the hypotheses and the overall hypothesized model, we conducted analyses in order to create a refined set of valid measures. A three-step approach was used to examine the influence tactics measure, which was examined separately from the endogenous variables. Because we combined items assessing six influence tactics from 
two different measurement instruments, whose dimensionality had not been well studied, and because there was reason to expect some overlap in item content across the various items composing the scales, we applied an exploratory approach to data reduction of the influence items. Thus, principal components analysis was used because it imposes fewer assumptions about the underlying structure of the data. First, the factor structure for the influence items was examined with a larger sample $(N$ $=463$ ) which included employees who had participated in the study but whose supervisors did not participate. The results of a principal components analysis with oblique rotation indicated that five items from the POIS measure (Kipnis \& Schmidt, 1982) loaded on the wrong factor, loaded on more than one factor, or had loadings of less than .40. After deleting these items, the remaining 20 items were submitted to a principal components analysis. There were no mixed loadings and all items loaded above .40 on their intended factors. Second, the factor structure for the reduced set of 20 items were then examined with the sample $(N=$ 247 ) used to test the hypothesized model. The items were submitted to a principal components analysis with oblique rotation, setting the number of factors to six. The results indicated that all of the eigenvalues were greater than 1.0 and accounted for $64.4 \%$ of the variance. All items had loadings of .40 or greater and loaded on the intended factors.

The 24 items measuring manager perceptions of skills, liking, perceived similarity, performance, and promotability of subordinates were submitted to principal components analysis with oblique rotation (due to expected intercorrelations between variables). Five factors emerged with eigenvalues greater than 1.0 and accounted for $69.1 \%$ of the variance. All items loaded above .40 on their intended factor and there were no mixed loadings.

Means, standard deviations, and intercorrelations among the variables are presented in Table 1. For the influence tactics, the zero-order correlations indicated that reasoning was positively related to interpersonal skills and performance ratings. Assertiveness was positively related to promotability assessments and higher authority was positively related to perceived similarity and promotability assessments. Finally, favor rendering was positively correlated with interpersonal skills, liking, and perceived similarity.

\section{Structural Equation Modeling}

Structural equation modeling was used to examine the hypothesized model. We used single indicators based on scale values for each variable and corrected for random measurement error because of the large 


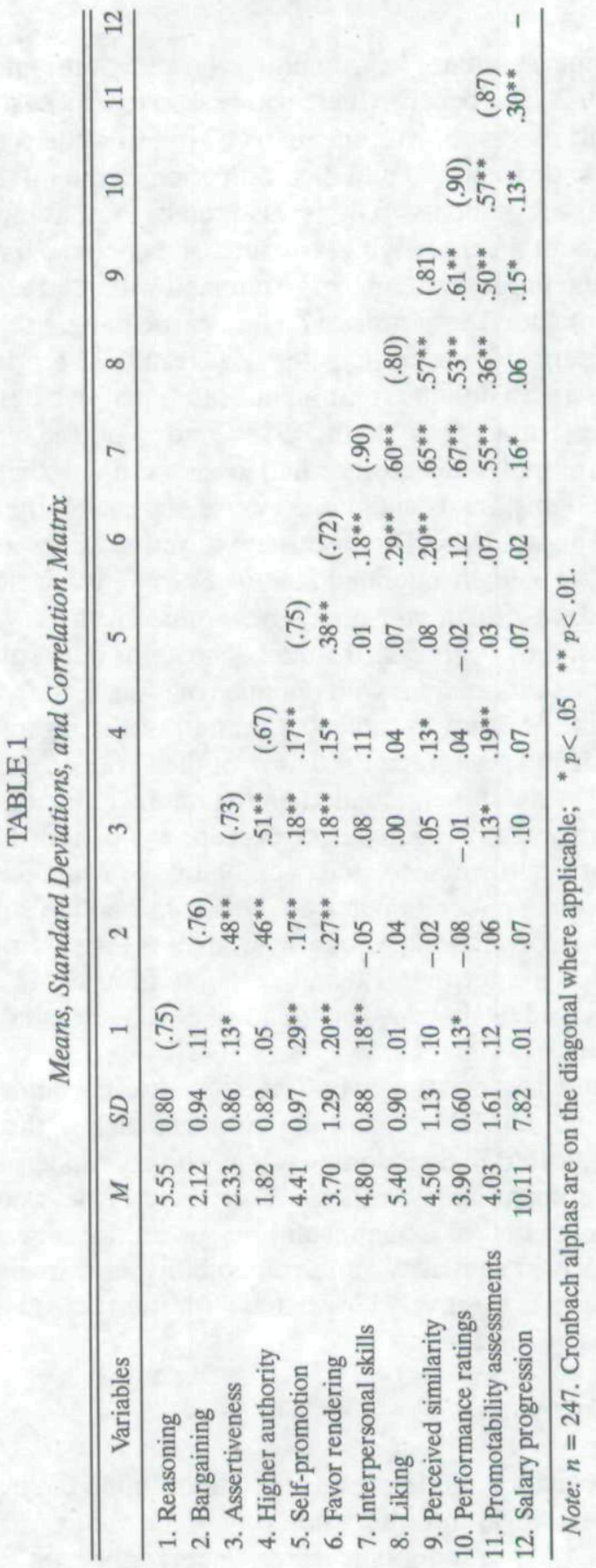


number of variables and parameter estimates included in the model. Using a single-indicator approach, the hypothesized model consisting of 19 path estimates was tested with a sample of 247 , resulting in a sample size to estimated parameter ratio of 13 , which exceeded the recommended minimum ratio of 5 (Bentler, 1985). It would not have been possible to meet the recommended minimum using a multiple-indicator approach.

In order to further assess the appropriateness of a single-indicator approach, we submitted each scale to a principal components analysis as advocated by Anderson and Gerbing (1988). The items for each variable were submitted to a principal components analysis with varimax rotation. For each variable, one factor emerged with an eigenvalue greater than 1.0. Further, all loadings were above .40 (results can be obtained from the authors). These results provide support for our decision to use a single-indicator approach. We adjusted for measurement error in the scale values, by setting the path from the latent variable to the indicator to the square root of the scale reliability. The error variance was set equal to the variance of the scale value multiplied by 1.0 minus the reliability (Hayduk, 1987; Jöreskog \& Sörbom, 1989). It was assumed that salary progression was measured without error; for this variable, the path from the latent variable to the indicator was set at one and the error variance was set at zero.

To test the structural model, a covariance matrix was used as input to LISREL 8.12 (Jöreskog \& Sörbom, 1993). The exogenous variables were assumed to be intercorrelated. Because prior research has not been able to determine causality between liking and perceived similarity (Byrne, 1971), a causal link was not examined. However, we estimated a parameter corresponding to the noncausal relationship between liking and similarity by allowing their disturbance terms to covary (Frone, Russell, \& Cooper, 1992). When the hypothesized model was modified by replacing the correlated disturbance terms with a causal path from perceived similarity to liking, the results were very similar to those for the hypothesized model. ${ }^{1}$

Figure 2 provides the maximum likelihood estimates of the hypothesized model. Among the upward influence tactics, subordinates who reported using reasoning more frequently received higher assessments of their interpersonal skills by their managers, providing support for Hypothesis 1a. Supporting Hypothesis 1b, bargaining and self-promotion

\footnotetext{
${ }^{1}$ Although perceived similarity and liking are significantly correlated (.57), they are not correlated so highly as to be redundant with one another. According to McNemar (1969), with perceived similarity and liking correlated .57 and perceived similarity correlated with a third variable .20 , the possible range of correlations for liking and that same third variable is from -.69 to .92 . This suggests that a correlation of .57 does not indicate redundancy. Furthermore, the results of the principal components analysis revealing two factors for liking and perceived similarity provide another indication of discriminant validity.
} 


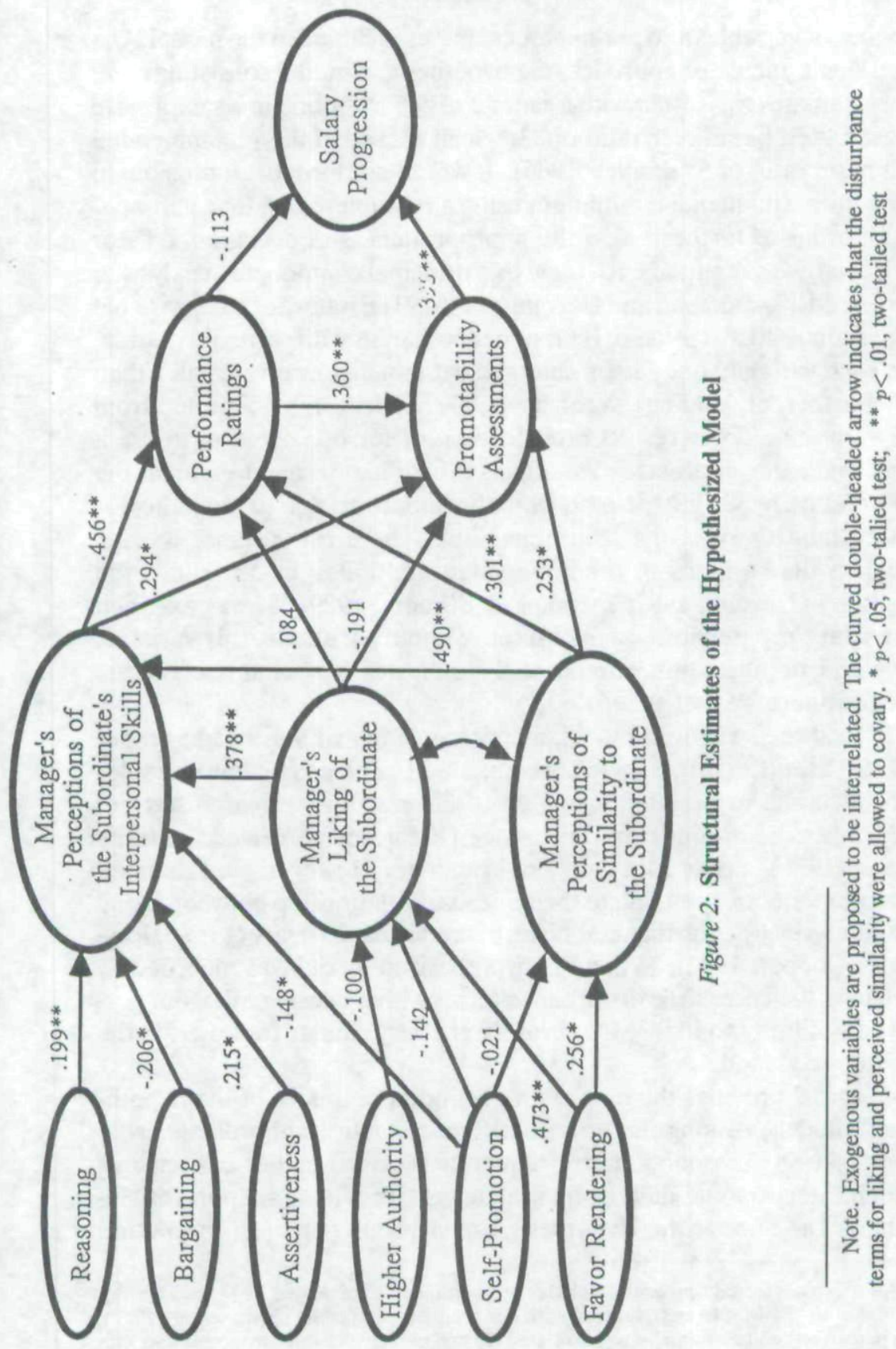


were negatively associated with assessments of interpersonal skills. However, contrary to Hypothesis $1 \mathrm{~b}$, assertiveness was positively associated to managers' assessments of skills. Consistent with Hypothesis 2a, favor rendering was positively related to liking. However, Hypotheses $2 b$ and $2 \mathrm{c}$ were not supported as self-promotion and higher authority were not related to liking. Favor rendering was positively related to similarity, supporting Hypothesis 3a, but Hypothesis 3b was not supported as self-promotion was not related to similarity.

Examining the relationships among the endogenous variables indicated that managers' liking of and perceived similarity to the subordinate were related to assessments of interpersonal skills. In terms of the variables related to performance ratings, subordinates who were rated higher on interpersonal skills also received higher performance ratings. Perceived similarity, but not liking, had a significant path to performance ratings providing partial support for Hypothesis 4. Similarly, interpersonal skills and perceived similarity were positively related to promotability assessments, but liking was not significantly related to promotability. Performance ratings also was positively related to promotability assessments. Thus, Hypothesis 5 received partial support. Finally, in partial support for Hypothesis 6, promotability assessments, but not performance ratings, was positively related to salary progression.

The fit statistics for the hypothesized model indicate the degree to which the model fits the data. The chi-square was 32.654 ( $d f=30, p$ $=.338$ ), indicating a good fit between the data and the model. The fit indices for the overall model were: goodness of fit index $=.979$, adjusted goodness of fit index $=.945$, normed fit index $=.964$, non-normed fit index $=.993$, and comparative fit index $=.997$. All of the fit indices were above .9 , suggesting that the data fit the proposed model very well (Medsker, Williams, \& Holahan, 1994).

In addition to the direct effects, reasoning, bargaining, assertiveness, and favor rendering had significant indirect effects on performance ratings $(.09,-.09, .10, .26$, respectively) and promotability assessments $(.09$, $-.09, .10, .16$, respectively). Reasoning, assertiveness, and favor rendering were positively related whereas bargaining was negatively related to these outcomes. Although these relationships were statistically significant, the relationships were extremely weak. In addition, none of the influence tactics had significant indirect effects on salary progression.

\section{Tests of Alternative Models}

The hypothesized model was compared to a series of nested models through sequential chi-square difference tests (Anderson \& Gerbing, 1988). First, the hypothesized model was compared to an unconstrained 
model where one or more parameters constrained in the hypothesized model are estimated. If the chi-square difference for these two models is not significant, the theoretical model is accepted due to the preference for parsimony (Anderson \& Gerbing, 1988; Williams \& James, 1994). The first unconstrained model examined whether influence tactics are directly related to performance ratings, promotability assessments, and salary progression. Thus, paths from each of the influence tactics to performance ratings, promotability assessments, and salary progression were added. The chi-square for this model was $15.385(d f=12, p=.221)$ and the chi-square difference was 17.269 with 18 degrees of freedom which was not significant. A second unconstrained model examined included adding a path from higher authority to perceived similarity. The chi-square for this model was $31.683(d f=29, p=.334)$ and the chi-square difference was 2.96 with 2 degrees of freedom which was not significant. A third unconstrained model examined consisted of adding a path from favor rendering to interpersonal skills. The chi-square for this model was $32.648(d f=29, p=.292)$ and the chi-square difference was 1.991 with 2 degrees of freedom which was not significant. The results of the unconstrained models suggest that adding these linkages to the hypothesized model does not significantly add to the explanatory power of the model. Given the preference for parsimony, the hypothesized model was preferred to the unconstrained model (Anderson \& Gerbing, 1988).

The second test is to compare the hypothesized model to a constrained model, meaning that one or more of the paths in the theoretical model are removed from the model or set equal to zero. For the constrained model, the following paths in the hypothesized model were constrained to zero: liking to performance ratings, liking to promotability assessments, perceived similarity to performance ratings, and perceived similarity to promotability assessments. Thus, the constrained model suggested that liking and perceived similarity are related to interpersonal skills which, in turn, is related to performance ratings, promotability assessments, and salary progression. The change in chi-square between the hypothesized model and the constrained model reflects the effect of removing those paths and thus is a test of their significance to the model. The chi-square for the constrained model was $50.974(d f=$ $34, p<.05$ ) and the chi-square difference between the constrained and hypothesized model was 18.32 with 4 degrees of freedom which was significant $(p<.01)$. Thus, the hypothesized model is preferred over the constrained model (e.g., Anderson \& Gerbing, 1988). Finally, the hypothesized model was compared to the structural null model. The structural null model is where all parameters relating the constructs to one another are constrained to equal zero. The chi-square for the null model 
was $566.415(d f=50, p<.001)$ and the chi-square difference was 533.761 with 20 degrees of freedom which was statistically significant $(p<.01)$, indicating that adding the links as proposed in the hypothesized model significantly improved model fit. In summary, the tests of the nested models provide support for the hypothesized model.

\section{Discussion}

Our proposed model suggested that influence tactics impact human resource decisions by affecting managers' perceptions of the subordinate's interpersonal skills, manager liking of the subordinate, and managers' perceptions of similarity to the subordinate. Although several linkages in the model were supported, the overall results indicated that employee influence tactics were not related to human resource decisions.

\section{Model Linkages and Contributions}

The results indicated that several subordinate influence tactics were related to managers' perceptions of subordinates' interpersonal skills. Specifically, subordinates who reported using reasoning received higher interpersonal skill assessments from their managers whereas subordinates who used bargaining and self-promotion tactics received lower interpersonal assessments from their managers. However, contrary to our prediction, subordinates who used assertive tactics were considered, by their managers, to have higher interpersonal skills. Overall, these results provide support for a positive relationship between subordinate influence tactics and managers' assessments of subordinates' interpersonal skills.

The positive relationship between assertiveness and interpersonal skills contradicts prior research that has found a negative relationship between assertiveness and outcomes such as performance ratings (Kipnis \& Schmidt, 1988) and promotability assessments (Thacker \& Wayne, 1995). One possible explanation for this finding may be that the managers and subordinates who participated in this study were primarily Caucasian and male. Carli (1989) found that men interacting with other men tended to be concerned with task issues and expressed disagreements whereas men interacting with females or females interacting with either males or females did not behave in this way. Carli concluded that "subjects' behavior is affected by their partners' gender" (p. 573). Further, Raggins and Sundstrom (1989) argued that in male-typed jobs, managers may value stereotypically masculine behaviors such as forcefulness and dominance. Given that both our manager and subordinate 
samples were predominantly male along with the prevalence of maletyped jobs (e.g., chemical sales, agricultural sales, research and development, and engineering), the managers may have perceived assertiveness as a desirable quality and expected assertive behaviors. Therefore, the use of such tactics may signal to the manager that the subordinate possesses the appropriate interpersonal skills for the position.

As expected, favor rendering was positively related to managers' liking of subordinates. If an individual receives favors from another person, the individual finds it more cognitively satisfying to like the person rather than dislike the person (Heider, 1958). Although we expected that subordinates' appeals to higher authority would be negatively related to managers' liking of subordinates, there was no relationship between this tactic and liking. One explanation may be similar to that discussed above regarding the relationship between the use of assertiveness and the manager's assessment of interpersonal skills. The use of appeals to higher authority might be considered ambitious and dominating which are considered male stereotypical traits (Raggins \& Sundstrom, 1989).

Favor rendering also was positively related to managers' perceptions of similarity to subordinates, as predicted. This represents a logical extension to the finding that liking and perceived similarity are highly correlated (Byrne, 1971; Liden et al., 1993). Although indices of similarity between supervisor and subordinate have been included in previous research (Ferris et al., 1994), these have tended to focus on demographic rather than perceived similarity (cf. Wayne \& Liden, 1995).

The intermediate linkages of liking, perceptions of subordinate's interpersonal skills, and perceptions of similarity were all hypothesized to demonstrate significant links to performance ratings and promotability assessments. Assessments of subordinate interpersonal skill and perceived similarity demonstrated significant and positive links with both performance ratings and promotability assessments, but liking showed no significant links to either of these outcomes. These results should be interpreted with caution given that these variables were all measured from the same source (i.e., manager).

Finally, our hypothesis regarding salary progression was partially supported; promotability assessments, but not performance ratings, was significantly related to salary progression. However, this result supports the contention of Beer et al. (1984) that an individual's potential rather than current performance is a stronger predictor of salary progression. Other factors, such as salary increments based on seniority or position in the pay range, may also explain the lack of relationship found between performance ratings and salary progression.

The present study extends previous research on upward influence in several ways. First, this study goes beyond previous research which was 
limited to simple direct associations between influence tactics and outcomes (Kipnis \& Schmidt, 1988; Thacker \& Wayne, 1995), and broadens the perspective by including potential intervening variables. By focusing on the three intermediate linkages of liking and assessments of interpersonal skills or competence and similarity suggested by Ferris and Judge (1991), the present study not only examined whether influence tactics affect human resource decisions but also examined the underlying processes. Previous attempts to model human resource decisions, which have focused almost exclusively on performance evaluation, have typically included only liking as a potential intermediate linkage in the model testing (Ferris et al., 1994; Judge \& Ferris, 1993; Wayne \& Ferris, 1990). However, without other potential intermediate linkages included, such models were incomplete. Second, the present study has taken account of the interconnectedness of many human resource decisions by examining performance evaluation, promotability, and salary progression in the same model. Third, whereas much of the previous work in this area has utilized a limited set of employee influence tactics (e.g., Ferris et al., 1994; Wayne \& Ferris, 1990; and Wayne \& Liden, 1995 examined only ingratiation and self-promotion tactics), the present study investigated a broader set of tactics.

Our focus on the indirect effects of upward influence tactics on performance ratings, promotability assessments, and salary progression is consistent with theory which has stressed that influence tactics operate on target perceptions of the agent (Jones \& Wortman, 1973; Wortman \& Linsenmeier, 1977). When influence tactics lead to positive target reactions, such as affect or favorable attributions, agent outcomes may in turn be affected. Although we found significant relationships between influence tactics and managers' perceptions of subordinates' interpersonal skills, manager liking of the subordinate, and managers' perceptions of similarity to the subordinate, only 3 of the 18 simple correlations between influence tactics and outcomes were significant.

One reason for the lack of significant effects between influence tactics and human resource decisions is the existence of additional intervening variables, such as target detection of an ulterior motive or target susceptibility to influence attempts, that were not included in our model. Another possible cause is that we assessed agent reports of the frequency with which they used influence tactics. Equally important, yet difficult to measure, is the effectiveness or quality of the way in which the agent executed the influence attempts. For example, if two individuals report the same frequency with which they use an influence tactic, but one individual is much more adept at using the technique, target reactions will probably be more positive for the agent who is more skilled at using the 
technique. Failing to account for the "quality" of the influence attempt may have introduced error.

\section{Limitations and Future Research Directions}

Despite the noted contributions, the present study is not without limitations. One limitation is that employee influence tactics were assessed based on subordinate self-reports, which potentially can introduce distortion through self-serving bias. Future research is needed that assesses influence tactics from independent sources such as peers. A second limitation of this study is that causality could not be determined due to the cross-sectional nature of the data. Longitudinal research is needed in order to examine the causal linkages proposed in the model. A third limitation is that the majority of the participants in the study were male and Caucasian. Thus, additional research is needed to determine whether the results of this study are replicated with a more diverse sample. Finally, although data were collected from both subordinates and their superiors, the paths from interpersonal skills, liking, and perceived similarity to performance ratings and promotability assessments involved variables based on manager reports. Thus, the stronger relationships among variables assessed from the same source suggest that common method variance may be a problem. However, there are reasons other than data source for higher correlations among some variables in the model in comparison to others. For example, we might expect the specific types of influence tactics to be intercorrelated. Similarly, different manager ratings of the same subordinate such as performance ratings and promotability assessments should be positively related (Cooper, 1981).

The next step for research in this area would be to longitudinally investigate the selection and effectiveness of different employee influence tactics over time as they affect career progress, specifically performance evaluation and promotions (e.g., Wayne \& Liden, 1995). Included in such models, in addition to influence tactics, should be personality variables which will permit the assessment of dispositional effects. Kilduff and Day (1994) demonstrated main effects of self-monitoring on career mobility, and Fandt and Ferris (1990) showed that high self-monitors tended to make greater use of influence tactics under certain conditions. If we can identify personality variables which might relate to one's perceptiveness and skill at using influence tactics at appropriate times, it would be useful to include such variables in models of human resource decisions. Ferris, Fedor, and King (1994) have proposed a conceptualization of managerial behavior which includes political skill as a key variable relating to the effective use of influence tactics and subsequent 
career success. However, more precise definition of the political skill construct is needed before incorporating it in human resources decision models.

\section{REFERENCES}

Anderson JC, Gerbing DW. (1988). Structural equation modeling in practice: A review and recommended two-step approach. Psychological Bulletin, 103, 411-423.

Atwater LE, Yammarino FJ. (1992). Does self-other agreement on leadership perceptions moderate the validity of leadership and performance predictions? PERSONNEL PSYCHOLOGY, 45, 141-164.

Baron RA. (1986). Self-presentation in job interviews: When there can be "too much of a good thing." Journal of Applied Social Psychology, 16, 16-28.

Beatty JR, McCune JT, Beatty RW. (1988). A policy-capturing approach to the study of United States and Japanese managers' compensation decisions. Journal of Management, 14, 465-474.

Beer M, Spector B, Lawrence PR, Mills DQ, Walton RF. (1984). Managing human assets. New York: Free Press.

Bentler PM. (1985). Theory and implementation of EQS: A structural equations program. Los Angeles: BMDP Statistical Software.

Bigoness NJ. (1976). Effect of applicant's sex, race, and performance on employers' performance ratings: Some additional findings. Journal of Applied Psychology, 61, 80-84.

Brass DJ, Burkhardt ME. (1993). Potential power and power use: An investigation of structure and behavior. Academy of Management Journal, 36, 441-470.

Bray DW, Howard A. (1980). Career success and life satisfactions of middle-aged managers. In Bond LA, Rosen JC (Eds.), Competence and coping during adulthood (pp. 258-287). Hanover, NH: University Press of New England.

Bretz RD, Milkovich GT, Read W. (1992). The current state of performance appraisal research and practice: Concerns, directions, and implications. Joumal of Management, 18, 321-352.

Byrne D. (1971). The attraction paradigm. New York: Academic Press.

Cardy RL, Dobbins GH. (1986). Affect and appraisal accuracy: Liking as an integral dimension in evaluating performance. Journal of Applied Psychology, 71, 672-678.

Carli LL. (1989). Gender differences in interaction style and influence. Joumal of Personality and Social Psychology, 56, 565-576.

Cialdini RB, DeNicholas ME. (1989). Self-presentation by association. Journal of Personality and Social Psychology, 57, 626-631.

Cooper WH. (1981). Ubiquitous halo. Psychological Bulletin, 90, 218-244.

DeNisi AS, Williams KJ. (1988). Cognitive approaches to performance appraisal. Research in Personnel and Human Resources Management, 6, 109-155.

Dreher GF, Dougherty TW, Whitely W. (1989). Influence tactics and salary attainment: A gender-specific analysis. Sex Roles, 20, 535-550.

Falbe CM, Yukl G. (1992). Consequences for managers of using single influence tactics and combinations of tactics. Academy of Management Journal, 35, 638-652.

Fandt PM, Ferris GR. (1990). The management of information and impressions: When employees behavior opportunistically. Organizational Behavior and Human Decision Processes, 45, 140-158.

Feldman JM. (1986). A note on the statistical correction of halo error. Journal of Applied Psychology, 71, 173-176. 
Feldman DC, Klich NR. (1991). Impression management and career strategies. In Giacalone RA, Rosenfeld P (Eds.), Applied impression management (pp. 67-80). Newbury Park, CA: Sage.

Ferris GR, Fedor DB, King TR. (1994). A political conceptualization of managerial behavior. Human Resource Management Review, 4, 1-34.

Ferris GR, Judge TA. (1991). Personnel/human resources management: A political influence perspective. Joumal of Management, 17, 447-488.

Ferris GR, Judge TA, Rowland KM, Fitzgibbons DE. (1994). Subordinate influence and the performance evaluation process: Test of a model. Organizational Behavior and Human Decision Processes, 58, 101-135.

Forbes JB. (1987). Early intraorganizational mobility: Patterns and influences. Academy of Management Joumal, 30, 110-125.

French JR, Raven BH. (1959). The bases of social power. In Cartwright D (Ed.), Studies in social power (pp. 150-167). Ann Arbor: University of Michigan Press.

Frone MR, Russell M, Cooper ML. (1992). Antecedents and outcomes of work-family conflict: Testing a model of the work-family interface. Journal of Applied Psychology, 77, 65-78.

Gardner WL, Martinko MJ. (1988). Impression management: An observational study linking audience characteristics with verbal self-presentations. Academy of Management Journal, 31, 42-65.

Gouldner AW. (1960). The norm of reciprocity: A preliminary statement. American Sociological Review, 25, 161-178.

Gurevitch ZD. (1984). Impression formation during tactical self-presentation. Social Psychology Quarterly, 47, 262-270.

Hayduk LA. (1987). Structural equation modeling with LISREL. Baltimore: Johns Hopkins University.

Heider F. (1958). The psychology of interpersonal relations. New York: Wiley.

Heilman ME, Block CJ, Lucas JA. (1992). Presumed incompetent? Stigmatization and affirmative action efforts. Joumal of Applied Psychology, 77, 536-544.

Heneman RL. (1973). Impact of performance on managerial pay levels and pay changes. Journal of Applied Psychology, 58, 128-130.

Hollander EP, Offermann LR. (1990). Power and leadership in organizations: Relationships in transition. American Psychologist, 45, 179-189.

Holtgraves T, Srull TK. (1989). The effects of positive self-descriptions on impressions: General principals and individual differences. Personality and Social Psychology Bulletin, 15, 452-462.

Johnson MA. (1989). Variables associated with friendship in an adult population. Journal of Social Psychology, 129, 379-390.

Jones EE, Wortman CB. (1973). Ingratiation: An attributional approach. Morristown, NJ: General Learning Press.

Jöreskog KG, Sörbom D. (1989). LISREL 7: A guide to the program and applications. Chicago: SPSSX.

Jöreskog KG, Sörbom D. (1993). LISREL 8: Structural equation modeling with the SIMPLIS command language. Hillsdale: Lawrence Erlbaum Associates.

Judge TA, Bretz RD. (1994). Political influence behavior and career success. Journal of Management, 20, 43-66.

Judge TA, Ferris GR. (1993). Social context of performance evaluation decisions. Academy of Management Journal, 36, 80-105.

Kilduff M, Day DV. (1994). Do chameleons get ahead? The effects of self- monitoring on managerial careers. Academy of Management Joumal, 37, 1047-1060. 
Kinicki AJ, Lockwood CA, Hom PW, Griffeth RW. (1990). Interviewer predictions of applicant qualifications and interviewer validity: Aggregate and individual analyses. Journal of Applied Psychology, 75, 477-486.

Kipnis D, Schmidt SM. (1982). Profile of organizational influence strategies. San Diego, CA: University Associates.

Kipnis D, Schmidt SM. (1988). Upward influence styles: Relationship with performance evaluations, salary, and stress. Administrative Science Quarterly, 33, 528-542.

Kipnis D, Schmidt SM, Wilkinson I. (1980). Intraorganizational influence tactics: Explorations in getting one's way. Journal of Applied Psychology, 65, 440-452.

Kumar K, Beyerlein M. (1991). Construction and validation of an instrument for measuring ingratiatory behaviors in organizational settings. Journal of Applied Psychology, 76, 619-627.

Liden RC, Mitchell TR. (1988). Ingratiatory behaviors in organizational settings. Academy of Management Review, 13, 572-587.

Liden RC, Wayne SJ, Stilwell D. (1993). A longitudinal study on the early development of leader-member exchanges. Journal of Applied Psychology, 78, 662-674.

London M, Smither JW. (1995). Can multi-source feedback change perceptions of goal accomplishment, self-evaluations, and performance-related outcomes? Theorybased applications and directions for research. PERSONNEL PSYCHOLOGY, 48, 803839.

London M, Stumpf SA. (1983). Effects of candidate characteristics on management promotion decisions: An experimental study. PERSONNEL PSYCHOLOGY, 36, 241-259.

Lowin A, Craig JR. (1968). The influence of level of performance on managerial style: An experimental object-lesson in the ambiguity of correlation data. Organizational Behavior and Human Performance, 3, 440-458.

Markham WT, Harlan SL, Hackett EJ. (1987). Promotion opportunity in organizations: Causes and consequences. Research in Personnel and Human Resource Management, 5, 223-287.

McNemar Q. (1969). Psychological statistics. New York: Wiley.

Medoff JL, Abraham KG. (1981). Are those paid more really more productive? The case of experience. Joumal of Human Resources, 16, 186-216.

Medsker GJ, Williams LJ, Holahan PJ. (1994). A review of current practices for evaluating causal models in organizational behavior and human resources management research. Journal of Management, 20, 439-464.

Michener HA, Schwertfeger M. (1972). Liking as a determinant of power tactic prefer-2 ence. Sociometry, 35, 190-192.

Mitchell TR, Liden RC. (1982). The effects of the social context on performance evaluations. Organizational Behavior and Human Performance, 29, 241-256.

Newcomb TM. (1961). The acquaintance process. New York: Holt, Rinehart \& Winston.

Pavett CM, Lau AW. (1983). Managerial work: The influence of hierarchical level and functional specialty. Academy of Management Journal, 26, 170-177.

Personnel Decisions, Inc. (1982). Management Skills Profile [Psychological Instrument]. Minneapolis, MN: Personnel Decisions, Inc.

Personnel Decisions, Inc. (1991). The PROFILOR® [Psychological Instrument]. Minneapolis, MN: Personnel Decisions, Inc.

Personnel Decisions, Inc. (1993). The Executive Success Profile [Psychological Instrument]. Minneapolis, MN: Personnel Decisions, Inc.

Raggins BR, Sundstrom E. (1989). Gender and power in organizations: A longitudinal perspective. Psychological Bulletin, 105, 51-88.

Robbins TL, DeNisi AS. (1994). A closer look at interpersonal affect as a distinct influence on cognitive processing in performance evaluations. Joumal of Applied Psychology, 79, 341-353. 
Ross L, Greene D, House P. (1977). The "false consensus effect": An egocentric bias in social perception and attribution processes. Journal of Experimental Social Psychology, 13, 279-301.

Rusbult CE, Lowery D, Hubbard ML, Maravankin OJ, Neises M. (1988). Impact of employee mobility and employee performance on the allocation of rewards under conditions of constraint. Joumal of Personality and Social Psychology, 54, 605-615.

Sahlins M. (1972). Stone age economics. New York: Aldine De Gruyter.

Schilit WK, Locke EA. (1982). A study of upward influence in organizations. Administrative Science Quarterly, 27, 304-316.

Schriesheim CA, Hinkin TR. (1990). Influence tactics used by subordinates: A theoretical and empirical analysis and refinement of the Kipnis, Schmidt, and Wilkinson subscales. Joumal of Applied Psychology, 75, 246-257.

Sherer PD, Schwab DP, Heneman HG. (1987). Managerial salary-raise decisions: A policy-capturing approach. PERSONNEL PSYCHOLOGY, 40, 27-38.

Spence M. (1973). Job market signaling. Quarterly Joumal of Economics, 87, 355-374.

Srull TK, Wyer RS. (1989). Person memory and judgment. Psychological Review, 96, 58-83.

Swann WB, Stein-Seroussi A, Giesler RB. (1992). Why people self-verify. Joumal of Personality and Social Psychology, 62, 392-401.

Thacker RA, Wayne SJ. (1995). An examination of the relationship between upward influence tactics and assessments of promotability. Journal of Management, 21, 739756.

Tsui AS. (1984). A role set analysis of managerial reputation. Organizational Behavior and Human Performance, 34, 64-96.

Tsui AS, Barry B. (1986). Interpersonal affect and rating errors. Academy of Management Joumal, 29, 586-599.

Turban DB, Jones AP. (1988). Supervisor-subordinate similarity: Types, effects, and mechanisms. Journal of Applied Psychology, 73, 228-234.

Wayne SJ, Ferris GR. (1990). Influence tactics, affect, and exchange quality in supervisorsubordinate interactions: A laboratory experiment and a field study. Joumal of Applied Psychology, 75, 487-499.

Wayne SJ, Kacmar KM. (1991). The effects of impression management on the performance appraisal process. Organizational Behavior and Human Decision Processes, 48, 70-88.

Wayne SJ, Liden RC. (1995). Effects of impression management on performance ratings: A longitudinal study. Academy of Management Journal, 38, 232-260.

Wayne SJ, Shore LM, Liden RC. (1997). Perceived organizational support and leadermember exchange: A social exchange perspective. Academy of Management Journal, 40, 82-111.

Williams LJ, James LR. (1994). Causal models in organizational behavior research: From path analysis to LISREL and beyond. In Greenberg J (Ed.), Organizational behavior: The state of the science (pp. 181-206). Hillsdale: Lawrence Erlbaum Associates.

Wortman CB, Linsenmeier JA. (1977). Interpersonal attraction and techniques of ingratiation in organizational settings. In Staw BM, Salancik GR (Eds.), New directions in organizational behavior (pp. 133-178). Chicago: St. Clair Press.

Yukl G, Falbe CM. (1990). Influence tactics in upward, downward, and lateral influence attempts. Journal of Applied Psychology, 75, 132-140.

Yukl G, Tracey JB. (1992). Consequences of influence tactics used with subordinates, peers, and the boss. Joumal of Applied Psychology, 77, 525-535. 
Copyright of Personnel Psychology is the property of Blackwell Publishing Limited. The copyright in an individual article may be maintained by the author in certain cases. Content may not be copied or emailed to multiple sites or posted to a listserv without the copyright holder's express written permission. However, users may print, download, or email articles for individual use. 